Konferans Bildirisi

\title{
Özne-Deneyim-Anı İlişkisinin Dijital İnşası: Seni Buldum Ya!
}

\author{
Lale Kabadayı (Prof. Dr.) \\ Ege Üniversitesi Illetişim Fakültesi \\ lale.kabadayi@ege.edu.tr \\ Başvuru Tarihi: 31.07.2021 \\ Yayına Kabul Tarihi: 11.10 .2021 \\ Yayınlanma Tarihi: 28.10.2021 \\ https://doi.org/10.17680/erciyesiletisim.977018
}

\section{Öz}

Zaman, bellek ve özne kavramları üzerine gerçekleştirdiği çalışmasında Arjantinli edebiyat ve kültür eleştirmeni Beatriz Sarlo, anıların, yaşayabilmek için bugüne ihtiyaç duyduğunu belirtmektedir. Buna göre, hatırlamak için tek uygun zaman anılara özgü zaman olan şimdiki zamandır. Anılar, bir uyaran yardımıyla zihne düşer, anlara bağlanır ve tutunduğu düşünceden uzaklaşmadan varlığını sürdürür. Sarlo, tanık olmaya yönelik fikirlerini açıklarken, deneyimin aktarımı için bireyin bedenle ve sesle geçmişin sahnesinde yer almasını gerekli görür. Özne, bedenen o an'a tanıklıkla anı olușturabilir ve sese sahip olduğu sürece anı aktarıcılığını devam ettirebilir. Sözlü paylaşıma dayalı deneyim aktarımı, sinema konu edildiğinde yeni oluşumlara imkân vermektedir. Yönetmen Reha Erdem'in, COVID-19 pandemisinin ilk karantina döneminde Zoom platformu üzerinden kaydederek kurguladığı filmi Seni Buldum Ya! anının aktarımı konusunda önemli bir örnektir. Seyirci, yakın geçmişte karakterlerle benzer şeyler yaşamış olsa da filmin aktardığı anların şimdiki zamandaki karşılı̆̆ı, özne-deneyim ilişkisinin yeniden inşasını içermektedir. Film, o anda var olmaya dair belleği çağırır ancak an'ı dönüştürüp tekrar yapılandırarak seyirciyi farklı anı oluşumuna yönlendirir. Çalışma, Seni Buldum $Y a$ ! filminin, belleğin kurulumunda şekillendirme yaptığı tezinden hareket etmekte ve filmin kültürel incelemeler bağlamında niteliksel olarak irdelenmesini içermektedir. İrdeleme sonucunda filmin geçmişe dair anıları bulanıklaştırarak kendi zamansallığını yarattığı ve yönetmenin sunduğu tekilleştirilmiş deneyim ile anlamı yeniden düzenlediği saptanmiştır.

Anahtar Kelimeler: Sinema, Anlatı, Özne, Deneyim, Bellek. 


\title{
Digital Construction of the Subject-Experience- Memory Relationship: Seni Buldum Ya! (Hey There!)
}

\author{
Lale Kabadayı (Prof. Dr.) \\ iD Ege University Faculty of Communication \\ lale.kabadayi@ege.edu.tr
}

Date Received: 31.07.2021

Date Accepted: 11.10.2021

Date Published: 28.10.2021

https://doi.org/10.17680/erciyesiletisim.977018

\begin{abstract}
In her work on the concepts of time, memory and subject, Argentinian literary and cultural critic Beatriz Sarlo states that memories need today to live. Accordingly, the only appropriate time to remember is the present, which is the commemorative time. Memories enter the mind with the help of a stimulus, connected to the moments and continue their existence without getting away from the thought they hold on. While Sarlo explains her thoughts on witnessing, she considers it is necessary for the individual to be on the stage of the past with body and voice for the transfer of experience. The subject can create a memory by witnessing that moment physically and can continue to transmit the memory as long as she/he has a voice. The transfer of experience based on verbal sharing allows for new formations when cinema is the subject. Director Reha Erdem's film, Seni Buldum Ya! (Hey There!), recorded on the Zoom platform during the first quarantine period of the COVID-19 pandemic, is an important example of transferring and creating memories. Although the audience has experienced similar things to the characters in the recent past, the present-time equivalents of the moments conveyed by the film bring up the reconstruction of the subject-experience relationship. The film invokes the memory of being in the moment, but by transforming and restructuring the moment, it directs the audience to the formation of a new memory. The study is based on the thesis that Seni Buldum Ya! film shapes the construction of memory and includes a qualitative examination of the film in the context of cultural studies. As a result of the examination, it was determined that the film created its own temporality by blurring the memories of the past and rearranged the meaning with the singularized experience presented by the director.
\end{abstract}

Keywords: Cinema, Narrative, Subject, Experience, Memory. 


\section{Giriş}

Bireylerin deneyimi, algılama anının öncelikli etkisi ve ardından zamanın şekillendirişi ile anı'ya eklenerek belleğe yerleşmektedir. Bu durumda anının belleğe dönüşümü, bireysel zaman algısının öznel kavrayışından hareket ederek biçimlenmektedir. Arjantinli kültür eleştirmeni Beatriz Sarlo, tarih yazımı ve belleği yeniden şekillendirme üzerine değerlendirmede bulunduğu Geçmiş Zaman kitabına şu cümleyle başlamaktadır: "Geçmiş her zaman tartışmalıdır" (Sarlo, 2012, s. 9). Bu tartışma içinde, bireyin deneyimlerinin önce anıya ardından belleğe dönüşmesinin öznel yönü vurgulanmaktadır. Sarlo, deneyim-anı-bellek ilişkisinde, deneyimin "bedene ve sese, geçmişin sahnesinde öznenin gerçekten mevcut olmasına” bağlandığını savunmaktadır. Buna göre anının oluşumu için öncelikle bir şeye tanıklık etmek gerekir, böylelikle deneyim oluşturulur. Ancak, hemen ardından, deneyimin aktarımı gelmek zorundadır. Çünkü; "Deneyimsiz tanıklık olmaz, ama anlatmadan deneyim de olmaz" (Sarlo, 2012, s. 21). Anlatı ile aktarılan, öznel deneyimi, olayın gerçekleştiği andan başka bir an’a yani zamansallığa taşımakta, onu 'hatırlama anı'nda kaydetmektedir. Buna rağmen söz konusu konumlama da sabit bir yapı sergilemeyecektir. Çünkü anlatının her aktarılışı ya da her yinelemesi, farklı değişkenleri öne çıkarabilecek ve güncelleşecek bir zamansallık yaratacaktır. Sarlo'nun "ısrarcı anılar" olarak adlandırdığı ve neredeyse otomatik olarak aniden zihne hücum eden anılar, kontrol edilemez özelliktedir. Onlardan kurtulmanın olanaksızlığı, anı ve zaman ilişkisinin diğer göreceli halini yaratmaktadır. Buna göre, "geçmiş kendiliğinden bugün olur" (Sarlo, 2012, s. 9). Anının söze dökülmesi ile deneyim genelleşir ve 'herkesin' haline gelir. Böyle bir zamansallaşma, deneyimin edinildiği an'ı, dile dökülme anına taşıdığı için, belki de yepyeni anıların oluşumunun deneyimi olarak algılanacaktır. Sarlo, kitabında, başat olarak Arjantin'in politik geçmişini konu edinmekle birlikte, özne-deneyim-anı ilişkisi için farklı alanlara dair önemli referanslar sunmaktadır. Bu çerçevede geçmiş üzerine düşünmek ve onu herhangi bir araçla aktarmak, anlamlandırma için irdelenmeye uygun mecralar oluşturur. Bu tartışma, bellek ve tarih arasında var olduğu düşünülen bir açık-alana dayanmaktadır. Buna göre, geçmişe gönderme yapma yetkisini, bellek ve tarih aralarında paylaşamaz. $\mathrm{Bu}$ nedenle, tartışma, deneyimleyen/aktaran arasında gelişen dikotomik bir yeniden ve yeniden oluşa ilerler. Tarihi yazan, onu deneyimleyen ve belleğe taşıyana tamamıyla güvenemezken, deneyimleyen de aktarımındaki eksiklik ya da fazlalıklar -kısaca yönlendirmeler- nedeniyle yazana güven duymamaktadır. Böyle bir yapılanma, iki tarafın da karşısındaki için yeniden inşa etme ihtimaline dair fikre sahip olduğunu ve bu inşayı olumsuzladığını ortaya koymaktadır. Olumsuzlama her alandaki aktarım için akla şu soruyu getirmelidir: "Deneyim, anlatıda eriyip gider mi, yoksa korunur mu?" (Sarlo, 2012, s. 20).

Kavramsallaştırmanın bu boyutuna ek olarak, deneyim-anı ilişkisi açısından bir yöne daha dikkat çekmek gerekmektedir. Kültürlerarası iletişimin getirdiği olanaklar ve sinema gibi güçlü iletişim araçları aracılığıyla anı oluşturma, deneyimi yaşayanların başına gelenlerin kişiselliğinin ötesine ilerlemekte, bireylerin, başkalarının deneyimlerinden anı ve bellek edinmesine doğru evrilişine imkân sağlamaktadır. Buna göre deneyim, beyazperde/ekran aracılığıyla da olsa evrensel şekilde yaşananlara tanıklık etme, onları yepyeni anlamlara açık olacak şekilde görsel deneyimlemeye ve belleğe yerleştirmeye doğru yeni bir tanımı bünyesine almaktadır. Bu durum, anı ve bellek ilişkisinde birebir tanıklık etmeye ve gerçek'le kurulan bağa farklı bakış açısı ekler. Bireyin yaşadığı deneyimin algılanışının ve önce anıya sonra belleğe dönüştürülüşünün göreceli yapısına karşın, başkasının aktardığı deneyim-anı-belleğinin, onu iletişim aracı vasıtasıyla dinleyen/okuyan/ 
izleyenin deneyim-anı-belleğine dönüşmesi öznel/nesnel ikili zıtlığının değişmiş inşasını sağlamaktadır.

Şeylerin hız kazandığı dönemlerde yakın geçmişin de onun süratle belleğe dönüşmesini sağlayan zamansallık kavramına hizmet ettiğini düşünmek olanaklıdır. Özellikle COVID-19 küresel pandemisi gibi kriz dönemlerinde her şey hem çok hızlı olmak hem de çok yavaş geçermiş gibi hissedilmek zıtlığında zaman algısı üzerine yeniden düşünmeyi gerektirmektedir. Bu gibi durumlarda geçmişi gündeme getirme, yalnızca tarihi değerlendirmeler, akademik/kuramsal yayınlar ya da resmî ideolojik belirlenimleri işaret etmez, kültürün her aşamasında birden çok paydaşın konuya dahil olmasına etkide bulunur. Adorno'nun ifade ettiği gibi deneyim, sağaltıcı bir unutuş ile sağaltıcı bir anımsama arasında kalan süre olarak ele alındığında (Adorno, 2012, s. 58), çok yönlülügüun krizlerin anlamlandırılması ve belleğe yerleştirilmesinde aracı olarak devreye girişini adlandırmak olanaklı hale gelmektedir. Sinema bu noktada, sağaltıcı olabilen ancak en çok da deneyimi belleğe aktaracak anıları şekillendiren önemli bir aracı konumuna yerleșmektedir. Reha Erdem'in COVID-19 pandemisinin ilk karantina döneminde yayınlanan Seni Buldum Ya! filmi, özne-deneyim ilişkisini şekillendirmesi açısından dikkat çekici bir örnek oluşturmaktadır. Film, Türkiye'de Zoom platformu üzerinden kaydedilerek kurgulanmış ilk uzun metrajlı yapım olmasının yanı sıra seyircinin pandemi dönemine yönelik anılarının biçimlendirilmesine aracılık etmesi açısından da önem taşımaktadır. Çalışmada, Seni Buldum Ya! filminin pandemiye yönelik anıları ve dolayısıyla belleği yeniden şekillendirdiğine dair düşünce, filmin kültürel incelemeler kapsamında niteliksel olarak irdelenmesi ile tartışılmaktadır. Kültürel çalışmaların, yazın alanından gelen eleştiri yöntemlerine ek olarak altmış yılı aşkın süredir filmlere yönelik çözümlemede kullanıldığını hatırlatan Tinkcom ve Villarejo'nun, kültürel yaklaşımların geniş çerçevesinin araştırmacılar için sunduğu olanakları vurgulayışına bu aşamada dikkat çekilmelidir (Tinkcom ve Villarejo, 2001, s. 1). Bireylerin toplumsal ağlar içinde kurduğu ilişkilerin anı-deneyim oluşturma bağlamında sınırlandırılarak yeniden şekillendirmeye yönelik irdelemelere imkân vermesi, düşünceyi kültürel çalışmaların öngördügü alanın açık uçlu olasılıklarına yöneltmektedir. Kültürel okumaların, özellikle değişim yaşanan süreçlerin getirdiği dönemlerde bu açık uçlu ve çok yönlü irdelemeler için kullanılabilir oluşu, onun aktif durumu çözümlemede geçerliliğini sağlamaktadır. Bu doğrultuda kültürel çalışmaların, deneyim-anı-bellek ilişkisinin dijital kurulumunun sinemada takibini yapmada kullanılabilecek bir yöntemi, irdeleyicinin önüne getirdiği kabul edilmektedir.

\section{Evrensel Kriz Dönemi Olarak Pandemide Deneyimle Anı Oluşturmanın Değişimi ve Belleğin Yeniden Kuruluşu}

Kültür kuramcısı Terry Eagleton, G. Greene'in bir roman karakteri üzerine yapılan eleştiriyi aktarırken, "kendi yaşantısına dahil olamaması" özelliğinin karakterin en çarpıcı niteliği olduğunu belirtir (Eagleton, 2011, s. 80). Karakter, özellikle başkalarıyla karşılaşmalar yaşadığı kültürel düzlemde deneyim edinmekte, ancak bunları bir türlü içselleştiremediği, sanki başkasının başına geliyormuş gibi hissettiği anlamlandırmalar içinde yaşamaktadır.

Roman karakterinin yaşadığı anlamlandıramayışı, kitle iletişimi aracılığıyla farklı bir açıdan değerlendirmek olanaklıdır. Birey kendi deneyimlerini tanımlamada yabancılık çekerken, kültürel düzeyde ele alındığında benzer durumları yaşayan bireylerin kendileri gibi olanların deneyimlerini adlandırabildiği, onların konumları hakkında benzer duygu durumunu hissedebildiği halleri iletişim araçlarının ilettiği mesajlar ile yaşar duruma 
gelmiştir. Günümüzde özellikle kültürel çalışmaların temelindeki ifadelerde yer bulan bu görüş, Eagleton'ın ifadesiyle başkasının ne hissettiğini anlayabilmek için kendimize ait kabuğu kırmak zorunluluğundan bizi kurtarmakta, hatta bazı zamanlarda anlamlandırma yapabilmek için bu kabuğa daha da gömülmemizi gerekli kılmaktadır. $\mathrm{Bu}$ koşulda başka birinin durumunu anlayabilmek için kendi -yerel- deneyimimizi göz önünde bulundurmak, kültürlerarası anlam evreninin yaratılabilmesi için yeterli hale gelir. Karşımızdakini anlayabilmek için kendimiz olmayı bırakmamamız gerekir, aksi taktirde her iki tarafın da aslında birbirlerinden önce kendisini anlamasını sağlayacak olan iletişim yolunun açılması, daha baştan engellenmiş olacaktır (Eagleton, Kültür yorumları, 2005, s. 62). Buna karşın Maurice Halbwachs, toplum üyelerinin paylaştığı kelimelerin ve nosyonların uzlaşımlarını ön plana çıkararak, bunlara hizmet etmeyen hiçbir kolektif algının olamayacağını iddia etmektedir (Halbwachs, 2016, s. 341-342). Yazara göre nesneleri gördügümüz anda onları başkalarının da görebileceği biçimde zihnimizde canlandırırız. $\mathrm{Bu}$ durum, tamamıla dişsal olamayacak gözlemlerden bahsetmemizi gerekli kılar. Bu nedenle 'tamamen içsel olabilen, yani sadece bireysel hafızada muhafaza edilebilen bir anı' da olamaz (Halbwachs, 2016, s. 341). Bu doğrultuda birey, eski ile o anı birbirinden ayırdığı ölçüde yani zihni dıșsal nesnelere ve diğer insanlara yönelmiş olarak kendini terk ettiğinde geçmişi daha iyi hatırlamakta ve aynı ölçüde açık ve somut biçimlerde onu yeniden üretebilmektedir.

Farklı görüşleri zihinde tutarak, özellikle kültür sosyolojisinin, sosyal pratikler açısından kültürü, toplumsal düzenin kaçınılmaz şekilde iletişim halinde bulunduğu, kavramları tekrar ederek veya yeniden üreterek deneyimi sürekli kıldığı bir anlamlandırma sistemi olarak tanımlamasına dikkat çekmek mümkündür (Eagleton, Kültür, 1993, s. 11). Bu durumun sunduğu 'bütün yaşam biçimi' olarak algılanış, sanatın da içinde yer aldığı imgesel pratikler düzleminin kuruluşuna ve deneyimlerin çok geniş bireyler arasında paylaşılmasına aracılık etmektedir.

Kültürel çalışmalar perspektifinde deneyim ve anı oluşturma açısından önemli bir küresel kriz dönemi şeklinde ele alınabilecek COVID-19 pandemisinde, sadece bireysel ya da toplumsal değil, evrensel alanda da anlam değişimleri gerçekleşmiştir. Örnek olarak; eviçi alan algısında yaşanan farklılıklar, kent/taşra dikotomisine bakışta değer-hiyerarşik yapının yer değiştirmesi, çalışan kesimlere yönelik algıda yenilikler, çocuk/yetişkin ikili zıtlı̆̆ına dair anlamlandırmanın farklılaşması, toplumsal cinsiyet veya yaş üzerine geliștirilen yerleşikliği sarsılan fikirler gibi konular, yeni anlamların olanaklı olduğu bir ortam yaratmaktadır. Sadece bireysel kalmayan, toplumsal ve toplumlararası algılarda da değişikliği sağlayan bu düşünceler, kültürel ortamda; özneler arası-iletişim-deneyim oluşturma ve paylaşma, anı oluşturma, kamusal/özel alan ayrımı-kent-suç ilişkisi gibi yönlerde yeni araştırma ortamlarını sosyal bilimcilere sağlamaktadır.

Özel alandan ayrımlaşarak evrensel yeni anlamlar üreten pandemi koşullarında sinemanın da oluşumuna imkân verdiği farklı tanımlamaları içeren film örneği çerçevesinde konuyu incelemeden önce, birey-deneyim-anı-bellek kavramının kuramsal yapısı için, özne ve deneyimi ele alan Beatriz Sarlo’ya dönmek olanaklıdır. Sarlo, birinci tekil şahıs tanıklıklar ve anlatılarla günlük yașamın yeniden inșasının kamusal alanın gerekleri ve eğilimlerine yanıt verecek şekilde oluştuğunu dile getirmektedir (Sarlo, 2012, s. 100). Konuya eleştirel bir bakış açısı da geliştiren Sarlo'nun değerlendirmesiyle, yaşamın ve gerçekliğin bir parçasının alıntılanarak deneyimin hatırlanmasına yerleştirilip an'ın yeniden inşa edilmesi, birinci tekil şahsın ifadesinin değer kazanmasını ve öznel boyutun öne çıkmasını sağlar görünse de, aslında deneyimin aktarılmasının asıl karşılıklarını 
kültürel çalışmalarda bulmak olanaklıdır. Böyle bir yapılanmada geniş sayıdaki özneler arasındaki geçişlilik, anlamlandırma ve zaman-mekân tanımlarının tekrar ele alınmasına ihtiyaç gösterir.

Sarlo, anının tanımlanabilmesi için bugün'e muhtaç olunduğuna da vurgu yapmaktadır. Bu noktada, Sarlo'nun, H. Bergson'a ve G. Deleuze'e atıfla aktardı̆̆ı, “Anının kendine özgü zamanı, şimdiki zaman"dır cümlesine dikkat çekilebilir (Sarlo, 2012, s. 9). Cümlenin anlaşılması için Bergson'un süre kavramı önem taşımaktadır. Bergson, "sürede bir noktanın her türlü kavrayıştan kaçar" oluşunu dile getirirken, sürenin hafıza sahibi bir bilinç için var olacağını vurgulamıştır (Bergson, 2014, s. 50). Böyle bir yapı -Bergson'a göre eğer an'ların olduğu varsayılırsa- sürenin birçok an'la kavranabilir olmasını sağlar. Öyleyse zaman, lineer ilerleyişinden çok, eksiltili, parçalı ve atlamalı bir yapıya bürünerek, eskinin bugünde defalarca yaşanmasına yönelik hissi, deneyim-anı-bellek ilişkisine yerleştirecektir.

Beatriz Sarlo'ya göre, geçmişi içsel mantığı açısından anlama çabası, daha ilk başından iki sorunla karşılaşmaktadır (Sarlo, 2012, s.16). Bunlardan ilki, yeniden inşası gerçekleştirilen şey'in aslında karmaşık olan yapısından basite indirgenerek aktarılmasıdır. İkinci sorun ise bir özne perspektifinde geçmişe bakıldığında anlatının öznelleştirilme biçiminin oluşturacağı dar çerçevedir. Bu noktada, Adorno'nun deneyime ve anıya yaklaşımına yönelinir. Adorno'nun ifadesiyle, anılar, geçmişte sabit kalamaz, çünkü geçmiş şimdiye bağlanır (Adorno, 2012, s. 173). Bu durumda, istemeden de olsa anımsanmaya mahkûm olan deneyim, aslında nasıl ilk halindeki gibi sabit kalamadıysa, hiçbir anı da onu zihninde saklayanın hatırlama ve aktarma zamanından etkilenmeyecek bir güven ortamı içinde varlığını sürdüremeyecektir. Çünkü geçmişte yaşanmış olan her şey şimdinin etkisiyle aktarılabilirdir. Şimdi ise, geçmişi, anlamını değiştirerek 'çürümeye' yönlendirir. Bu yüzden "(...) geçmişi şimdinin çamurlu akıntısının dışında tutmaya çalışmak da aptalca bir duygusallık olur. Geçmişin tek umudu, yıkıma savunmasızca maruz kaldıktan sonra, onun içinden farklı bir şey olarak çıkma olasılığıdır" (Adorno, 2012, s. 173).

Deneyimin, değişken algılanışı ile başlayan, aktarılışı ile yeniden şekillenen, zamana ve mekâna dair dönüşümlere açık olan yapısı, Adorno için bir yeni-anlamlandırmaya dair bir ümidi taşımaktadır. Deneyimler insan yaşamını derinden etkileyecek kadar güçlü olduğunda değişime uğrama ihtimalleri artmaktadır. Buna göre, yașanan, bireyin taşıyabileceğinden çok daha ağır bir yük haline dönüştüğünde "birey de onu deneyimlemek yerine sezgisel bilgiden tümüyle kopuk kavramlarla doğrudan doğruya kaydeder: Yaşanan, dişsal bir şeydir artık, ölçülemeyen, karşılaştırılamayan bir şey" (Adorno, 2012, s. 187). Bu durumda öznelliğin içinde gerçekleşse de oradan bağımsızlaşarak yeni bir anlama bürünen deneyim, kamusala aktarıldığında yine farklı anlamlara ulaşacak yani yine evrilecek, sonuçta, bir kısmı saklanacak şekilde anonimleșecektir.

Deneyimin, toplumsal alanda, bireyin kimliklenmesine etkide bulunan yönü, aslında özel olan kimliğin yalnızca kamusal mekânda tanımlanma ve onaylanma yoluyla genel kabul görmesiyle kendini göstermektedir. Deneyim, belli örüntülerin yeniden üretimlerini basitleștiren ve bu örüntüleri 'saklı tutan' kolaylaştırıcı süreçleri içermektedir (Draaisma, 2014, s. 255). Karşılıklı deneyimin düşünceler olarak iletildiği ve bir anlamda eleştirel fikir alışverişi olarak nitelendirilecek bu deneyim paylaşımının kendisi de bir kamusal alan oluşturur (Taylor, 2006, s. 110). Bu noktada, persona kavramına değinmek gerekir. Nurdan Gürbilek'in sahicilik/rol, doğallık/maske benzetmesinde ifadesini bulduğunu vurguladığı, Antik Yunan'da oyuncuların sahnede taktıkları maskelere dayanan persona 
terimi, günümüzde 'kişi'ye karşılık kullanılmaktadır. Persona kavramında olduğu gibi, bireyin kendisi ile kamuya gösterdiği arasındaki farka benzeyen bir deneyim aktarma niteliğinin gerçekliği, anı oluşturma/aktarma durumunun değişkenliğini özetler. Gürbilek'in ifadesine göre; kamusal alanda bireyler, kişisel geçmiş, durum ve hislerini açığa vurmayarak, hatta tam da bu yüzden başkalarıyla ilişki kurabilmektedir (Gürbilek, 2001, s. 59). On sekizinci yüzyılın büyük şehir yaşantısına kadar geri götürülebilecek bu ilişki kurma biçimine göre, bireylerin doğal yollardan birbirleri hakkında fikir edinme olanağı yoktur. Özel alanın mahremiyeti devam etse de her türlü yabancıyla ilişki kurabilmek için bir çaba gerekmiş; kamu yaşamının canlılığı, sonraki yüzyılda belirginleşecek olan öteki kavramına dair anlamsal evrenin kurulumuna zemin hazırlarken, ortak alanlar, anlamları, paylaşılabilecek kabuller düzeyinde tutmayı gerekli kılmıştır. Paylaşımların belirli kalıplar içinde anlamlı hale geldiği bu ortak alanlar, daha sonra, yerel olmayan, daha geniș ortak mekân türünü yani Charles Taylor'ın ifadesiyle 'metatopikal mekân'ları yaratmıştır (Taylor, 2006, s. 92). Kısmen ortak anlayışlarla oluşturulan bu tür mekânlar ortaklık temasının yokluğunda ortadan kalkacağı gibi, aynı zamanda sadece onlara da indirgenerek anlamlandırılmamış, başlangıçta kamusal alandan farklı düşünülen metatopikal mekânlar, ardından tam da onun anlamına karşılık gelecek şekilde kullanılmaya başlanmıștır. Bu mekânlar kamusal alanın hemen ilk uygulanışındaki, örneğin 'yönetime kllavuzluk edecek rasyonel görüşlerin incelikli işlendiği bir mahal' olmamıştır (Taylor, 2006, s. 94). Modern dönem bu kapsamı değiştirmiş ve toplum anlayışını geliştirip dönüştürerek; "toplumun üyelerinin fikir alışverişinde bulunup ortak bir fikre varabildikleri yeni bir metatopikal mekân” (Taylor, 2006, s. 105) anlamına gelen kamusal alan tanımlamasını yaratmıștır. Böyle bir metatopikal ortak mekânda, insanların bir arada birbirleriyle iletişimde bulunması, toplumu 'metatopikal bir fail' konumuna taşımaktadır (Taylor, 2006, s. 106-108). Taylor, on sekiz veya on dokuzuncu yüzyılın kent uzamlarını, katılımcıların tümünün birbirini görebildiği aynı yerde oluşla 'topikal' uzam içinde tanımlarken, yirminci yüzyıl ile birlikte iletişim teknolojisinin bu uzamların metatopikal varyantlarını ürettiğine dikkat çekmektedir. Örneğin kitle iletişim araçları önünde gerçekleşen bir olay, tüm dünyada yankı uyandırabilmekte ve bu olaya katılımımızın anlamı, onun paylaşıldığı dağınık ve geniş seyirci kitlesi ile şekillendirilir olmaktadır. Başka bir yerde gerçekleșen ve failin bașına gelen olaya dair görüntü ve sesin paylaşımı ile genelin deneyimine dönüşen eylemler, anı'nın yeni yapısını belirlerken, deneyim-anı ilişkisini birebir yaşanma zorunluluğundan azat etmektedir. $\mathrm{Bu}$ durum başlangıçta bir sözde-tarih ve bir sözde-kültür ortamı yaratabilir görünmektedir. Ve "(...) gerçek bir deneyimden hareketli değil ama kodun öğelerinden ve aracın teknik güdümlemesinden hareketle yapay olarak üretilmiş olayların, tarihin, kültürün üretilmiş düşüncelerin dünyasına" (Baudrillard, 2017, s. 159) atıfta bulunur şekilde algılanabilir. Ancak böyle bir inşa, Baudrillard'ın dile getirdiği estetik değerlerin bağışıklığını yitirdiği bir simülasyon alanı veya estetik yanılsamanın sonunu işaret eden trans-estetik (Baudrillar, 2002, s. 64, 308, 316) bir özellik göstermekten daha çok, sanatın yeniden tasarlanma olanağına sahip modern bir parçası olarak iletişim ürününün ya da özelde bir filmin estetik yanılsamasını hâlâ güçlü halde devam ettirebildiğini işaret etmektedir. Ortaya konan ürün, böylelikle, kötü bir kopya olmaktan öteye gider, yeniden inşayı önemseyen bir estetize etme hali olarak var olur.

Yaşananların aktarımında, bireyin ya da toplumun deneyimlediği her şeyin ifadesinde dilin kullanımı kadar dil dıșının pratik alana taşınması da söz konusudur. Gürbilek, söz ile denetlenip aktarılarak yaşananların tüketilebildiği bir ortamda dil dışına itildiğimizi savunmakta ve "Yaşantıları koparıldıkları tarihe iade etmek mümkün olmadığına göre, 
yaşantılara koparıldıkları tarihi iade etmek" gerektiğini söylemektedir (Gürbilek, 2001, s. 50). Ancak böylelikle kendisini bize yansızmış gibi gösteren söz düzenini adlandırılarak geçmişin tarihini ortaya koymak olanaklı hale gelecektir. Gürbilek, bu noktada, Jameson'a atıfla, deneyim-anı-bellek ilișkisinde 'bugün' yapılması gerekenin, bazı bilgileri geri planda tutarken bazılarını ısrarla dille ilişkilendiren ve yaşananları istediği gibi şekillendiren söz düzeninin yapısının ve bu durumda saklı hale gelen pratiklerle güç ilişkilerinin gizlenmiş konumlarının ortaya konmasına yönelik bir 'zihinsel haritacılığa' ihtiyaç duyulduğunu belirtir. Zihinsel haritacılık, sadece birincil anlam veya rahat okunan yan anlamları değil, zaman içinde dilin ya da genel olarak sembolik alanın kullanımındaki değişikliği de kapsamalı, göstergelerin gizil farklı anlamlara doğru ilerlemesine dair ifade evrenini ortaya çıkarmamıza aracılık etmelidir.

Andreas Huyssen'ın ifadesiyle, dil, anlatı, görüntü veya kaydedilmiş sesi kapsayan tüm temsil biçimleri, deneyimin aktarımında yaşanacak bütün değişimlere rağmen halen belleğe dayanmakta ve belleği hatıra getirmektedir (Huyssen, 1999, s. 13). Bu doğrultuda, özellikle kitle iletişim araçları, bireyde 'katışıksız bir şimdilik yanılsamasını' yaratmakta ve bellek de, geçmişi sürekli yeniden üreterek değiştirdiği için temsile dayanmaktadır. Bellekte yalın halde bulunmayan geçmiş, dile getirilerek anı haline gelebilmekte, bu doğrultuda bir olayı deneyimlemekle onu anımsamak için temsilden yararlanmaya ihtiyaç duyulmaktadır. Huyssen, bu ihtiyacı zayıflık olarak görmektense, kültürel ve sanatsal yaratıcılık ile ilişkilendirmektedir. Anımsama geçmişte yaşanmış bir olaya veya deneyime bağlı olsa dahi, bellek geçmişin değil şimdinin yapısı ile yaratıcı şekilde canlı tutulmaktadır. $\mathrm{Bu}$ durumda bellek, bazı an'ların unutuluşuna izin verirken diğerlerini temsil ile bireysel ve kültürel anımsamaya taşımaktadır.

Huyssen'ın dile getirdiği anımsamalar; 'zamanın geçişine ve teknolojik modernleşmenin kesintisiz hızına bağlı olarak yitmekte olan kuşaksal anımsamalar' ile 'belleğin ayrıcalıklı zamanı olarak değerlendirilebilecek 'alacakaranlık' statüsünü yansıtan anımsamalar' olmak üzere iki türde kendini göstermektedir (Huyssen, 1999, s. 14). Alacakaranlık, zamanın kendisini yavaşlatır görünen bir anıdır. Bu noktada bellek, depolama ve gerektiğinde yeniden hatırlama işlemini sürdürmektense, şimdiki zamanı işaret eden kültürel bir olguya dönüşmüş durumdadır. Huyssen, bu aşamada bir paradoksa dikkat çekmektedir. Yüksek teknolojinin hızlı değişimi; geçmiş/gelecek, yaşantı/beklenti, bellek/gelecek kategorilerinin çok kısa zamanda dönüşmesine neden olmakta ve çağdışı kalmasına yol açmaktadır. Yeni iletişim teknolojileri ortamında kalan bireyin zamansallık kavrayışı da buna göre şekillenecektir. Bu nedenle, 'tarihsel bilincin yok oluşu'na dair söylemin kendisi, tarihsel olarak tanımlanmaya ihtiyaç duyan bir olguya dönüşmüştür. Buna rağmen, bellekle ilgili düşüncelerdeki aşırı artış, Huyssen'e göre insani bir gereksinim olarak sağlıklı bir mücadele işareti olarak da değerlendirilmelidir. Hatta iletişim araçlarının karşısında bir tutunma pratiği olarak dahi değerlendirilebilir. $\mathrm{Bu}$ durumda, yüksek teknolojiye dayandırılmış distopik gelecek tasavvurunda bellek yitimi, anımsama ile unutma arasında kurulabilecek dikotominin parçası olmaktan çok, onun 'radikal ötekisi' konumuna taşınacaktır. 0 halde bellek yitimi, bir kayıp olarak algılanmaktan çıkacaktır. Çünkü; "Anımsanacak bir şey olmadığına göre, unutacak bir şey de yoktur" (Huyssen, 1999, s. 21).

Ele alınacağı konuya göre olumlu başlayıp kötümser bittiği düşünülebilecek olan bu fikir, Adorno'nun 'deneyimin bir görüş açısı hatta en iyi ihtimalle bir hipotez olduğu' iddiasına uzatılabilir (Adorno, Negatif diyalektik, 2016, s. 39). Buna göre deneyimin öznel payı ile nesne deneyimi arasındaki fark kapanmayacak, hatta bilen öznenin zorunlu hissettiği 
ve acı verici şekilde gerçekleştirdiği gayretleri bu farkı üretmeye devam edecektir. Adorno'nun bakışındaki özneden hareket eden bir düşünüşün yanlışlardan kurtulamaz olacağının vurgulanarak olumsuzlanması durumu, bireysel deneyimin hâlâ özneye bağlı olarak tanımlamasını eleştirmektedir. Adorno'ya göre, tarihsel olarak bitmiş kabul edilmesi gerektiği için 'eski' hale geldiği düşünülen özne, kendi-için olduğunu düşünse de artık kendinde değildir (Adorno, Minima moralia- sakatlanmış yaşamdan yansımalar, 2012, s. 16). Özne, kendi bilincine ve deneyimine güvenerek bireyseli aşan sezişi inkâr ettiği ölçüde, her an aktardığıyla kendisi arasındaki ilişkiyi olumsuz alana iletme olasılığını taşımaktadır.

Öznenin kendine ve deneyime ettiğini, Gürbilek'e göre, dil siyaseti özneye etmektedir. Özneye ait eylemin dışarıda bırakıldığı bir dil siyaseti, geçmişe ait olanı bugünün ihtiyaçları doğrultusunda yeniden tanımlamakta ve geçmişi bugünün imajları içinde çabuk üretilip tüketilen bir unsura çevirmektedir. Dil siyasetinin geçmişi bu şekilde pop imgelerle simgelemesi, Jameson'ın ifadesiyle, onu bir "pop tarih" haline getirir (Gürbilek, 2001, s. 49).

Bütün bu yaklaşımlar, geçmişin her zaman tartışmalı olduğu bir ortamı olanaklı kılmakta, iletişim araçlarının devreye girmesiyle bireye bağlı gibi görünen deneyimden hareketle aslında anı ve bellek oluşumu toplumsallaşmakta veya evrenselleşmektedir. Deneyimlerini içselleştiremeyen ve bu doğrultuda kendi yaşantısına dahil olamayan karakterlerin ön plana çıktığ yeni anlam evreni, bir yanda gelișen yabancılaşma durumuna, iletişim araçları ürünleri ile başkalarının deneyimlerine tanıklık edilen çoğullaşmış anılar eklemektedir. $\mathrm{Bu}$ durumda anının tamamen bireysel olması imkânsız hale gelmekte, herkesi kapsamına alan ve genişleyen sınırlar içinde somutlaşmış üretimlerle yeniden ve yeniden tanımlanan anılar karşısına çıkmaktadır. Bu noktada anlamlandırmanın üretenin tekilleştirme riski taşıyan tanımlamasına dair durumunu adlandırabilmek için, seçilen örneğe, Reha Erdem'in Seni Buldum Ya! filmine yönelmekte yarar bulunmaktadır.

\section{Kuramsal Çerçeve Kapsamında Seni Buldum Ya! Filmine Yönelik İrdeleme}

İstanbul'un karantina altında olduğu dönemi temeline alan Seni Buldum Ya! filmi, pandemide iletişim kurma yöntemlerinde yaşanan değişikliklere dayalı ortak deneyimlerimizin yarattı̆̆ gerçeklik gücünden yararlanan bir öyküyle, internet üzerinden dolandırıcılık yapan Kerim (Bülent Emin Yarar) ve Felek (Serkan Keskin) adındaki iki erkeğin öyküsünü ekrana taşımaktadır. Kerim ve Felek, Dördüncü Daire adını verdikleri ve yargı organına bağlı olduğunu ileri sürdükleri sözde siber çevik kontrol kurumu aracılığıyla dolandırıcılık yapmaktadır. Kerim, dolandırılacak kişileri bulmakta, Felek ise bu kişilerin bilgisayarına sızıp görüntülü bağlantı yoluyla onları daha önce yaptıkları ahlaki olmayan eylemler veya işledikleri suçlar ile korkutmaktadır. Kişileri, hesaplarına para yatırırlarsa suçlarının silineceğine ikna etmeye çalışan Felek, ağabeyi gibi gördüğü Kerim ve bilgisayar ekranıyla yaşamlarına temas ettiği yedi kurban ile kurduğu dijital iletişimde, bireysel olan veya olmayan yeni anılar edinir. Ancak bir yandan da her görüşmesinde aldatılarak kaybetmeye doğru adım adım ilerler.

Yüz yüze iletişimin kesintiye uğradığı, film izleme kadar film üretme pratiklerinde de değişikliğin yaşandığı bir dönem olarak COVID-19 pandemisi, Reha Erdem'in ifadesiyle, "film çekmek için büyük kameralara" hatta kameraya bile ihtiyaç duyulmayan bir aşamayla bizleri tanıştırmıştır (MUBI, 2021). Şimdilik son uzun metrajlı kurmacası olan Seni Buldum Ya! filminin hemen hemen tamamını Zoom platformu üzerinden aldığı kayıtları kurgulayarak gerçekleştiren Reha Erdem, tarihe not düşme ve onu yeniden 
şekillendirme ilişkisi açısından sinemanın üstlendiği görevde, yakın geçmişe dayanan anıları belleğe aktarma konusunda yeniden-inşacı bir tutum sergilemektedir. Pandeminin ilk karantina döneminde tamamlanan film, 2021 yılının Mart Ayı'nda MUBI platformu üzerinden gösterime açılmıştır. Dolandırıcı Kerim ve Felek üzerinden, zamanın ruhunu kara-komedi türünde tanımlamaya çalışan film, Beatriz Sarlo'nun vurgusundaki gibi; hayatın dokusundaki gerçeği, deneyime sırtını dayayarak, ancak yine de ondan ayrı bir anı oluşturacak şekilde yeniden kurgulamaktadır. Film, deneyim-tanıklık etme ilişkisini farklı bir düzleme yerleştirmektedir. Deneyimsiz tanıklık etme gerçekleşemeyeceği için ama anlatılmadan deneyim de olamayacağı için yönetmen, filmde pandemi deneyimini izleyici için adlandırmakta, ancak hepimizin benzer şekilde yaşadığı veya yaşayabileceği anıları kendi özne konumuna göre şekillendirmekte ve kendi deneyim düşüncesine dayalı bir yakın geçmişi belleğimize yerleştirmektedir. İzlendiği andan itibaren 'herkesin anısı' haline gelen film, başka bir zamansallık içinde hatırlama anına kaydolmaktadır. Böylelikle yönetmenin deneyimi, 'gerçek'i bize sürekli hatırlatsa da, bizzat bizce yaşanmadan, izleme deneyiminin ardından anlamlandırılır hale gelmekte ve belleğe yerleşmektedir. Annette Khun, kültürel hafızaya eşdeğer olarak sinema belleğini öne çıkardığı kitabında filmlerin insanların kișisel belleklerinin bir parçası haline geldiğini dile getirmektedir (Khun, 2002, s. 6-7). Khun, bu doğrultuda, etnotarih kavramını sinema deneyimi ile ilişkilendirir. Yazılı-olmayan kültürlerin tarihi olan etnotarih, Khun'un kullanımıyla sosyal antropolojiye dayanan kökenine rağmen, kaynak materyallerine ve verilerine dayanan diyalektik, söylemsel ve bağlama duyarlı bir yaklaşımla irdelemeyi ön plana çıkarmaktadır. Böylelikle anlatı-tarih ve bellek ilişkisi kurulabilir. İzleyicinin günlük yaşamına entegre edilmiş olan sinema, farklı deneyimlere açıklığıyla filmleri kültürel hafızanın bir parçasına dönüştürmektedir. Film izleme deneyimi, dijital ortamda daha da kişiselleşerek belleği ortak kültürel yapıyla kurmaktadır.

Bununla birlikte, Reha Erdem'in filmdeki evren aktarımı, Gürbilek'in ifade biçimi olarak dil üzerine düşünülmesi gerekliliğine dair vurgusunu hatırlayarak da açıllanabilir (Gürbilek, 2001, s. 49). Gürbilek'in dil aracılığıyla fiili saf dışı bırakmanın mümkünlüguünü dile getirmesi gibi, geçmişte yaşananlar günün fantezi ve ihtiyaçları doğrultusunda tanımlanarak bugün yaratılan imajlar içindeki bir alıntıya dönüştürülmekte ve Jameson'ın pop tarih dediği hale getirilen geçmiş, deneyimden de anıdan da farklı yepyeni bir oluşum olarak tanımlanabilir hale gelmektedir.

Seni Buldum Ya! filmi benzer bir anlam evreni inşa eder. Pandemi gibi bir krizin karmașık yapısı, filmde farklı karakterlere rağmen kimin kimi dolandırdığı konusu üzerinden tekil anlam oluşumuna indirgenir. Yönetmen, yaratıcı özne olarak tanımlandığında, onun öne sürdüğü perspektif, doğal olarak anlatıyı da öznelleștirmektedir, ancak dijital olanla özellikle pandemi sırasında kurduğumuz ilişkinin yarattığı gerçeklik hissinin yoğunluğu nedeniyle bir yandan da belleğin oluşumunda yakın geçmişi kendi görüşü çerçevesinde anonimleştirmektedir. Geçmişi, kamerasıyla değil ama kurgusuyla 'yeniden yazan' yönetmen, önce'ye gönderme yaparmış gibi görünen filmiyle bu kez alımlamanın öznesi izleyici sayısı kadar çeşitlenebilecek anıya yön verir, belleği herkes adına ama herkesten bağımsız şekilde oluşturur. Filmin temel olarak yaptığı, pandemi sürecine ilişkin benzer kültürel anıları aktarma yoluyla tekilleștirmek ve belleği dönüștürerek, onu kuran sosyal yönlerin diğer önemli kısımlarını bir anlamda geri plana itmektir. Burada, amacın, sinemada materyal gerçeğin aranmasına yönelik duyulan kaygı olmadığı belirtilmelidir. Seni Buldum Ya! filminin yönetmeni Reha Erdem, özne-deneyim-anı ilişkisinde söze-sese sahip bir tarih yazıcısı olarak, anıların zihnimizdeki yerini ve önemini değiștirmekte; ona 
dair rahatsız edici, sıkıcı hatta üzücü hisleri silme isteğimizi dönüştürerek, belleği, ortak kabul edilebilir, katlanılabilir naif bir veriden ibaret hatıraya dönüştürmektedir.

Dolandırıcılık hikâyesi üzerinden insanların evlerine 'sızan' başkarakter Felek'le kurulan ilişki, onun bilgisayar ekranından avlarıyla kurduğu ilişkiye benzer. Felek'in farklı evlerde yaşayan farklı meslekten kişilerle bilgisayar üzerinden görüşmesi, özel alan kavramının anlamını değiştirir. Felek, onları, kamusallaştırılmış özel alanları içinde tehdit ederken, seyirci de Felek'i kendisinin kurduğu 'kamusal alanmış gibi eylenen' evinde izlemektedir. Kamusallaşmış özel hayatlar dönemini sosyal medya aracılığıyla yaşadığımız bu zamanda, kamu kavramının en bașlarda "topluluğun tümünün malı olan" (Gürbilek, 2001, s. 57) șeyler anlamına da geldiği akılda tutulmalıdır. Sınırlarının dijital ortamda iyice belirsizleştiği özel alan/kamusal alan ayrımında, özneler, Antik Yunan oyuncularının maskeleri gibi-personaları ile tipleştirilmektedir. Vurgulamak gerekirse günümüzde kişi'yi belirtmek amacıyla kullanılan persona, maskenin ardındakini, maskenin koruduğunu, rolün gizlendiğini ifade etmektedir. Sahicilik/rol, doğallık/ maske benzetmesiyle persona, kişinin deneyim aktarımında da devrededir. Filmde tüm karakterlerin mesleklerini kötüye kullanması ve günlük yaşamlarındaki ahlaki olmayan tutumları, bir yandan birbirlerine karşı sürdürdükleri avlama/avlanma ilişkisinin altyapısını kurar, bir yandan da kamusallaşan bilgisayar ortamında gizlenmeyi sağlayan personaların/maskelerin çıkarılarak güven, ahlak, suç kavramlarının herkes için konu edilebileceğinin değerlendirilmesine olanak verir. Dijital deneyimler, gerçek gerçeğin var olmadığı ve bir süre sonra da buna aldırılmadığı bir ortam sunar. Filmdeki kullanımıyla da dijital platform, bir anlamda yansıma platformudur; kaydettiği karakterler ekran çerçevesinin boyutuyla sınırlı yaşam sunumu içinde geçici süreyle tanık olunan personalar gibi işler ve anlamlandırmanın izni ekran süresiyle belirlenir. Burada karakter özelliğinden çok, kurgulanmış bir tipler topluluğu bulunmaktadır. Tiplere vermemiz beklenen önem, onlara ayrılan süre ve bilgisayar kamerasının nereyi görüntülediği ile belirlenmektedir. Bununla birlikte, özneymiş gibi çeşitlendirilen tiplerin hiçbiri, dağınık görüntü parçacıkları nedeniyle merkezi konumlarını tam olarak elde edemez. Dans etme, gülme, âşık olma, korkma, alay etme gibi özellikleri özetlenen tipleri karakter yapacak olan ve toplumsallaştıran eylemlerin anlamları boşaltılır. Bilgisayar ekranına bakan seyirci de, benzer bir izlenme ediminin metaforik konumuyla işaretlenir.

Günlük tanımlamada kamusal kavramını en yoğun taşıyacak olan kent ile kurulan ilişkinin çoğunlukla mekân-insan ilgisine dayalı yapısı da, filmle kesintiye uğramaktadır. Kent, filmde yönetmenin pandemi yasağında omuz kamerasıyla bir arabanın içinden çektiği boş sokak görüntüleri, çeşitli evlerin pencerelerine yaklaşan ve uzaklaşan düzensiz hareketteki kayıtları ve sadece bir sahnede Felek'in hoșlandığı kadının evini bularak onu ziyaret etmesi talebiyle dışarıya çıkması dışında, bağ kurulmaz şekilde biçimlenir. Felek'in para koparmaya çalışırken tehdit ettiği insanların evinin önüne diktiği kişi ile bu kişiyi görmek için pencerelerinden bakanların algısı haricinde dışarısı, yani ilk anlamıyla kamusalı tanımlayanla ekstra bir bağ kurulmaz. 0 halde yönetmenin el kamerasıyla kaydettiği kent sokaklarındaki çekimlerde de, dolandırıcılık kurbanlarının pencereden bakışında da kentin içine girilemez. Özel olanla kamusal olan arasındaki sınırı çizen büyük şehir içindeki yaşantı yıkıma uğrar, kamu ev içinde kurulur. Gürbilek'in, bireylerin, kişisel geçmiş, durum ve hislerini açıklamadan başkalarıyla ilişki kurabileceklerine dair yorumu (Gürbilek, 2001), dijitalle kurulan ilişkide yıkılır, olumlu-olumsuz birçok anlamı barındırabilecek olan kamu hayatı, bir bilgisayar ekranı üzerinden görüşerek de, onu kaydedip film üreterek de, yeniden inşa edilir. 
Soyutlanmış alanların bireyleri; bilgisayar ortamı üzerinden neredeyse terapiye karşılık gelecek şekilde sohbet etme ve müzik dinleyerek dans etme aracılığıyla insanlıklarını sürdürür halde verilmektedir. Reha Erdem'in diğer filmlerinde de görülen stilize edilmiş mekânlar ve uzak durulan karakterler, yönetmenin biçimci/yapay sinema anlayışı ile tutarlıdır. $\mathrm{Bu}$ anlamda bilgisayar üzerinden film kaydetme fikrinin yönetmenin dünya görüşüyle biçimsel bir anlam evreninde örtüştüğünü dile getirmek mümkündür. Özneler arası iletişimin bilgisayar çerçevesi sınırına indirgendiği ortamda '-miş gibi' yapma veya olmanın uzun zaman sürdürülebilirliği, dolandırıcının dolandırılması ile sonuca bağlanır. Filmde yaratılan evrenin yapay kişileri de, anının zihinsel sürece hatırlatılmasında mimetik olanı vurgulayan bir temsiliyet içine hapsedilir. Belleğin depolama ve gerektiğinde yeniden hatırlama işleminden çok kültürel olgu şeklindeki kavranışı (Huyssen, 1999, s. 13), özel/kamusal alan ayrımının ortadan kaldırılmasıyla, yönetmenin temsile bağlı aktarışına uyumlu hale getirilir. Jale N. Erzen'in belirttiği gibi, nesne ve olguların temsil edilmesi, yani tanımlanıp isimlendirilmesi bellekle ilgili bir işlemdir (Erzen, 2016, s. 60). Bu yapılanmada sanat, belleğin önemli bir rolünü üstlenen özel bir dil olarak değerlendirilmelidir. Algılanan şey'i anlamlandırabilmek için ona farklı bir açıdan bakmak gerekir. Şey, ancak hayal gücü veya zihin tarafından yeniden yaratıldığında anlamlı hale gelir. Bu aşamada temsil, algılanan şeyi birey için sabit kılar. Aslında temsilin, olguyu anlam açısından çoğaltabilme özelliği de vardır, belleğe aracılık eden temsil, gereksinimlere göre değişik anlamalara da işaret edebilir. Bu doğrultuda sanat içinde temsil, bakana göre değişiklik gösterme potansiyeline sahip olsa da, yaratıcısının bakışını ileten güçlü bir yöntemdir ve farklılıklara rağmen anlaşılmayı öngörür. "Bu da belleğin ve temsiliyetin hem hatırlama hem de unutma aracı olduğunu göstermektedir" (Erzen, 2016, s. 60-61).

Eğer geçmiş her zaman tartışmalı ise, yönetmen bu tartışmada olumlu bir pandemi geçmişini tercih etmiş görünmektedir. Deneyimlenmesi tamamlanmış ama anıya dönüşmesine izin verilmemiş olaylar gibi asla olduğu şekilde gösterilemeyecek bir kriz döneminin, bilgisayar ekranındaki yansıması, dış çekimlerdeki evlerden 'herhangi bir evde olmaktadır' hatırlatmasını yaparak pandemiyi anonimleştirmekte ama onu bağlamından uzaklaştırarak, herkesin herkes için av ya da avcı olduğu düşüncesini önemseyen, yeniden anlam evrenine oturtan bir aracı gibi hareket etmektedir. Bunun nedeni, karantina gibi bir durumun karmaşık yapısının, bu filmde tekil anlam oluşumu çerçevesine indirgenmesidir. Yönetmenin özne haliyle öne sürdüğü perspektif, doğal olarak anlatıyı da öznelleştirir, bir yandan da belleğin kuruluşunda bıraktığı izler nedeniyle anonimleşmesine yol açar. Çünkü, "modern kitle toplumundaki tüketim kültürünün insanlık dışı anonimliğine ancak fantezi yoluyla katlanılabilir"dir (Belton, 2008, s. 415). Film, bu fantezi-kurgu ortamını başarıyla oluşturur. Filmin zamanı, aynı anda, yeniden şekillendirilmiş olan gerçeğin ve şimdinin zamanı olma talebinde bulunmaktadır. Dijital ortamın yarattığ parçalanmış zaman anlayışı, ara sıra bağlanılan sohbetlerle kesik-kesiklik hissini duyumsatır. Film seyri sırasında, zihindeki yakın geçmişin anıları, kendini izleyiciye sürekli hatırlatmaktadır. Geçmiş ile bilgisayar ekranında görülen sohbet arasındaki dijitale dayalı gerçeklik kurgusu, bir yılı aşkın süredir dijital platformlar üzerinden sürdürülen iletişimin sürekli o anda olma hissini hatırlatmasından yararlanır, gerçek algısına sırtını dayayarak seyir deneyimine oyun oynar.

Pandemi tecrübesini, insanlık üzerine bir düşünme aracı olarak yeniden kurgulayan Reha Erdem, öznel kavrayışına dayalı bir deneyim gibi yorumladığı film konusunu anılarımıza eklemektedir. Tanıklık etme ekran üzerinden gerçekleşmektedir. Aktarılanın her seferde 
değişikliğe uğrayacak olmasına karşın anı gibi zihne yerleşecek izlemeye dayalı bu deneyim, sinema aracının kaydetme gücüne bağlanarak sabitlenmektedir. Öyleyse bu dışsal deneyim, değişime kapanarak anlatıda korunur hale gelir. Yaratılan yeni deneyimin anonimliği onu öznenin ilk elden yaşama özelliğinden ve bu yolla anı'ya dönüşmesinden uzak bir noktaya taşımaktadır. Bu doğrultuda Seni Buldum Ya! özelinde pandemi deneyimi tekilleşmekte ve yalın şekilde onu izleyenin deneyim-anı-belleğine dönüşmektedir.

Burada belleğin zamanı, ardışıklık ilkesini yıkmaktadır. Ve Bergsoncu düşünüş çerçevesinde 'birbiri içine geçirilmiş hallerden bahsedilmesi' karakterler bazına indirgenir. Bergson'un kastettiği düzenlemede, "her hali başka bir hal içine kendini deforme ederek bir hal içine sokulmakta" olan bir hal/süreç bulunur, böylelikle yeni bir anlama dönüșen süre(ç) bu haliyle korunur duruma gelir (Bergson, 2014, s. 50-51). Süre, ileriye uzanan bir düz çizgi olmaktan çlkarak genişleyen bir çembere dönüşmekte ve haller bilinçte birbirleri içine girmiş vaziyette yapılanmaktadır. Böyle bir durumun filmde de geçerli oluşu, bilgisayar ekranından tanıklık edilen yaşamlarla kurulan ilişkinin iç içe geçmiş karakterlerinden aslında adeta tek bir yaşamın öyküsünü çıkarmaya doğru ilerletilmektedir. Bu da, Reha Erdem'in hemen her filminde sorduğu "İnsan nedir ki?" sorusuna yanıt arar nitelikteki ‘birey üzerine düşünme’yi işaret etmektedir.

Pandemi gibi, insan yaşamını derinden etkileyecek kadar büyük evrensel kriz dönemlerinde deneyimlemenin dışsallığına yapılan vurgu, onun birbirinden kopuk kavramlarla ve parçalı zaman algısıyla kaydedilmesine etkide bulunmaktadır. Adorno'nun "sağaltıcı unutuşla sağaltıcı anımsama arasındaki süre" olarak tanımladığı deneyimi bizlere özdeneyim gibi algılatan Reha Erdem, kendi yaşantımıza doğrudan dahil olmayan ama başkasının tanıklığında yeni anıları kendi anılarımıza dönüştürüp belleğe yerleştirme kabulünü, kültürel düzeyde çok sayıda bireyin paylaşımına açık bir alanda gerçekleştirmemizi sağlar. Böylece, bütün yaşam biçimi olarak algılattığı ve bireyselden kültürele oradan da evrensele ulaşan pratikler düzleminin örneğini, perdeye/ekrana taşıyıp içselleștirmemizi doğallaştırır.

Metatopikal bir varyant olarak dijital platform üzerinden kaydedilerek kurgulanan bu uzun metrajlı film, özne/faillerin deneyimlerinin genellendiği ve anonimleștiği bir fikir alışverişi ortamına dönüşmüştür. Bu ortamda film radikal bir öteki olmasına rağmen anı'yı ve belleği oluşturmayı, 'şimdi yanılsaması' içinde sunmaktadır. Filmle şekillenen anı-bellek, sadece aktarılırken değişime uğramakla kalmamış, kaynağı adeta unutularak yeniden yaratılmıştır. $\mathrm{O}$ halde kriz dönemlerinin bireysel/ toplumsal/evrensel anılarının bellekte bıraktığı ize sinemanın bu modern dokunuşu, geçmişin her zaman tartışmalı ortamına bir ek daha yapmakta ve onu popüler tarih alanına taşıyarak, ister ikili ister tekil yapılanmalarla, değer atıfsız şekilde anlamı yeniden inşa etmektedir.

\section{Sonuç ve Değerlendirme}

Öznel deneyimin önce anıya ardından belleğe dönüşümüne dair lineer ilerleyişi tanık olmanın birincil anlamlandırmasından bağımsızlaștıran iletişim araçlarının ürünleri, hatırlama anlarının zamansallığını kendi istediği șekle göre belirleme gücüne sahiptir. Her yeni ürünle birlikte eski, bugünde defalarca yeniden yaşanırken, anılar deneyimlendikleri an'dan koparak anlatıldıkları şimdiki zamanların koşullarıyla şekillenmekte ve belleğe yerleşmektedir. Sinema eseri yaratıcısının özne olarak tekilleşen düşüncesini perdeye/ ekrana taşıması, deneyimin adlandırılması ve anlamlandırılması açısından seyirci üzerinde etkide bulunmaktadır. Kişisel belleği yeniden şekillendirme gücünü gösteren etki, deneyim-anı bağını, söze-sese-görüntüye dökenin tanıklığına teslim etmektedir. 
Seni Buldum Ya! filmi ile Reha Erdem'in düzenlediği anlatı seyircinin zihninde yer ederken geçmişin tartışmalı konumu yönetmence saptanmış bir zamansallıkta sabitlenmektedir. Film, bireysel olarak yaşamadığı bir deneyimi hatırlarmış hissini seyirciye duyumsatır, bir yandan da onu genelleștirerek herkesin anısı haline getirir. Özne olarak artık orada bulunmasına ihtiyaç duyulmayan ve kendi deneyimlerini geri plana atarak başka olası deneyimleri anıya dönüştüren seyirci, film aracılığıyla devraldı̆̆ bu anıları zihnine yerleştirir. Seni Buldum Ya! filminde böylelikle bireysel deneyim anlatıda erimekte, yönetmence öznelleştirilmiş alanda inşa edilmiş bir kurulum ve pratikle anıyı düzenleyerek bağımsızlaştırıldığı geçmişi miş’leștiren bir yapı kurulmaktadır.

Filme yönelik gerçekleştirilecek bir zihinsel haritacılık çabası, hem çoklu karakter yapısı hem de zamanı kesintiye uğratmak için kullanılan parçalı görüntülerden oluşan biçiminin, kara komedi türü içinde alınan hazzın ötesinde sorgulanmasını gerekli kılar. Zamanın ruhunun belirsizliğini içeriğe ve biçimsel özelliklerine taşıyan film, gerçeklik deneyimine dayanan ama onun yalnızca bir yönünün ortaya çıkarılmasına yol açan bir anı yaratarak deneyim-anı-bellek ilişkisini yeniden kurgulamaktadır. Reha Erdem, özneliğinin getirdiği söze ve sese bağlı olarak bir anı aktarıcısına dönüşmektedir. Yönetmenin gerçekleştirdiği ve geçmişin bulanıklaştırıldığı bu aktarıcılık, deneyimi bir yandan eritirken bir yandan da ona yeni bir bakış açısı kazandırmaktadır. Yönetmenin deneyimi ve anısı, seyircinin deneyimi ve anısını alacakaranlık statüsüne taşır. Böylelikle seyircinin belleği, filmin ele aldığı zamana sabitlenen kültürel bir olguya dönüşmektedir.

Reha Erdem'in Seni Buldum Ya! filmi, pandeminin devam ettiği bu dönemde de gelecekte -umarız- bittiği günlerde de her izlemede, anlatıcı/aktarıcı olduğu zamanın tekil deneyim örgüsünü güncelleyerek zamansallığı kendi ürettiği anlamda sürdürecek, gerçekle kurulan bağ anlatıda değişikliğe uğrarken anı yeniden ve yeniden üretilerek pandeminin kültürel bellekteki yerini dolduracaktır. Filmin anlatımı estetize ederken tercih ettiği nokta, benzer anıların edinildiği bir dönemde pandemiye dair çok yönlü karşılıkları geri plana itmekte oluşu ve küresel krizin zihinlerdeki yerini değiștirerek onu silme isteğini öne çıkarıp belleği ortak kabul edilebilir ve katlanılabilir bir veriye dönüştürmesidir. Pandemi içinde hızla akan olayların kişilerde bıraktığı izlerin hafifletilmesine aracı olarak yeni anlamları öne süren film, bireylerin ihtiyaç duyduğu sağaltıcı bir unutuş isteğinin yakın hatırasına dönüşme ihtimalini taşıması açısından olumlu bir potansiyel şeklinde seyircinin karşısında durmaktadır.

\section{Kaynakça}

Adorno, T. (2012). Minima moralia- sakatlanmış yaşamdan yansımalar. (O.Koçak\&A. Doğukan, Çev.) İstanbul: Metis.

Adorno, T. (2016). Negatif diyalektik. (Ş. Öztürk, Çev.) İstanbul: Metis.

Baudrillard, J. (2002). Tam ekran. (B. Gülmez, Çev.) İstanbul: YKY.

Baudrillard, J. (2017). Tüketim toplumu. (N. T. Keskin, Çev.) İstanbul: Ayrıntı.

Belton, J. (2008). American cinema, American culture. New York: McGraw-Hill.

Bergson, H. (2014). Metafizik dersleri-uzay-zaman-madde. (B.G.Beşiktaşlıyan, Çev.) İstanbul: Pinhan.

Draaisma, D. (2014). Bellek metaforları-zihinle ilgili metaforların tarihi. (G. Koca, Çev.) İstanbul: Metis.

Eagleton, T. (1993). Kültür. (S. Aydın, Çev.) Ankara: İmge. 
Eagleton, T. (2005). Kültür yorumları. (Ö. Çelik, Çev.) İstanbul: Ayrıntı.

Eagleton, T. (2011). Kötülük üzerine bir deneme. (Ş. Bezci, Çev.) İstanbul: İletişim.

Erzen, J. (2016). Çoğul estetik. İstanbul: Metis.

Gürbilek, N. (2001). Vitrinde yaşamak-1980'lerin kültürel iklimi. İstanbul: Metis.

Halbwachs, M. (2016). Hafizanın toplumsal çerçeveleri. (B. Uçar, Çev.) Ankara: Heretik.

Huyssen, A. (1999). Alacakaranlık anıları-bellek yitimi kültüründe zamanı belirlemek. (K. Atakay, Çev.) İstanbul: Metis.

Khun, A. (2002). An everyday magic-cinema and cultural memory. London and New York: I.B. Tauris Publishers.

MUBI. (2021, Mart 13). HEY THERE! Online Gala. HEY THERE! Online Gala: https://www. youtube.com/watch?v=nT-uBMnPKDI adresinden alındl.

Sarlo, B. (2012). Geçmiş zaman-bellek kültürü ve özneye dönüş üzerine bir tartışma. (P. B. Ekinci, Çev.) İstanbul: Metis.

Taylor, C. (2006). Modern toplumsal tahayyüller. (H. Koyukan, Çev.) İstanbul: Metis.

Tinkcom, V. \& Villarejo, A. (2001). Introduction. In Villarejo \& Tinkcom, Keyframes: Popular cinema and cultural studies (pp. 1-29). London\&New York: Routledge. 


\title{
Digital Construction of the Subject-Experience- Memory Relationship: Seni Buldum Ya! (Hey There!)
}

\author{
Lale Kabadayı (Prof. Dr.)
}

\section{Extended Abstract}

The concept of memory is based on the experiences of the individual. The perception of the individual shapes the experience process. The experience of individuals settles in the memory with the primary effect of the perception process and then the shaping of time. This situation highlights a subjective understanding. Argentinian literary and cultural critic Beatriz Sarlo states that the past is always controversial. Memory reshapes the past both when recording and transferring it. The person refers to the present time when conveying the past. So, the time of memories spontaneously becomes the time of the present. Time takes on an elliptical and fragmented structure rather than its linear progression. The feeling of experiencing the past many times in the present is repeated in the experience-memory relationship. According to Eagleton, the sociology of culture defines culture in terms of social practices as a 'system of signification' through which the social order necessarily communicates, reproduces, sustains experiences, and turns to exploration. In the view of cultural studies, it is possible to connect with the experiences of those around us and even individuals from different cultures through our own experience. The perception of the 'whole lifestyle' offered by this situation mediates the establishment of the practice environment in which art takes place and the sharing of experiences among a wide range of individuals.

Transferring the past with cinema films is of great importance in forming the memory of the audience. Witnessing events through movies becomes universal and the meaning of experience changes accordingly. In times of global crisis such as the pandemic, the events of the recent past are quickly settled in the memory. This situation creates areas that can be studied at every stage of culture. At this stage, cinema can shape the past as it wishes and place different experiences in the memory. What needs to be done in the experiencememory relationship is the necessity of doing 'mental mapping' for media products that highlight some memories while keeping others behind. Mental mapping should cover not only the primary meaning or connotations, but also the change in the use of language or the symbolic field in general over time and should mediate us to reveal the universe of meaning regarding the progression of signs towards different latent meaning.

Almost all the Reha Erdem's film Seni Buldum Ya! (Hey There!) was produced by editing the images recorded on the digital platform. Trying to define the spirit of the time, the film reconstructs reality by relying on experience but still creating a separate memory from it. From the moment it is seen, the film becomes everyone's memory and creates another temporality. When the director is defined as the creative subject, his perspective also subjectivizes the film narrative. At the same time, the director anonymizes the sense of 'reality' that the audience thinks in their relationship with the computer during the pandemic, within the framework of his own view. Reha Erdem changes the place and importance of memories in our minds, like a historiographer who has a voice in the subject-experience-memory relationship. The director ignores the disturbing and sad things about the pandemic and turns it into a memory of naive data that can be accepted as common. In the film, the distinction between private and public space loses its clarity 
and the relationship between the characters and the city is destroyed and the concepts of time and space are blurred. In this film of Reha Erdem, there are stylized places seen in his other films. The characters of the artificial universe created in the film are also made up of artificial types reminiscent of the personas in the theatre. The pandemic experience built around these people pushes the real meaning of the pandemic into the background. As a result, while the past is re-lived in the present, director Reha Erdem places a memory in the minds of the audience, arranged as he wishes. Reha Erdem, who reconstructs the pandemic experience as a means of thinking about humanity, adds the subject of the movie, which he interprets as an experience based on his subjective understanding, to our memories. Through this film, which was recorded and edited on a digital platform as a metatopical variant, Reha Erdem creates memory by adding a new meaning to the always controversial environment of the past.

Keywords: Cinema, Narrative, Subject, Experience, Memory.

Bu makale intihal tespit yazılımlarıyla taranmıştır. İntihal tespit edilmemiştir.

This article has been scanned by plagiarism detection softwares. No plagiarism detected.

Bu çalışmada "Yükseköğretim Kurumları Bilimsel Araştırma ve Yayın Etiği Yönergesi” kapsamında uyulması belirtilen kurallara uyulmuştur.

In this study, the rules stated in the "Higher Education Institutions Scientific Research and Publication Ethics Directive" were followed.

Araştırma tek bir yazar tarafından yürütülmüştür.

The research was conducted by a single author.

Çalışma kapsamında herhangi bir kurum veya kişi ile çıkar çatışması bulunmamaktadır.

There is no conflict of interest with any institution or person within the scope of the study. 